\title{
Formulasi Handbody Lotion (Setil Alkohol dan Karagenan) dengan Penambahan Ekstrak Kelopak Rosela
}

\author{
Formulation of Handbody Lotion (Cetyl Alcohol and Carrageenan) with Addition of Roselle Petal Extract \\ Maya Irmayanti ${ }^{1 *}$, S.Rosalinda ${ }^{1}$, Asri Widyasanti ${ }^{1}$ \\ ${ }^{1}$ Departemen Teknik Pertanian dan Biosistem, FTIP, Universitas Padjadjaran, Jl. Raya Bandung Sumedang KM.21 \\ Jatinangor, Kabupaten Sumedang 45363 \\ *E-mail: maya17001@mail.unpad.ac.id
}

Diterima: 10 Februari 2021; Disetujui: 6 Juni 2021

\begin{abstract}
ABSTRAK
Handbody lotion merupakan kosmetik yang dapat diaplikasikan pada kulit bagian tangan dan tubuh yang berfungsi untuk mengurangi dehidrasi kulit. Setil alkohol pada handbody lotion memiliki fungsi sebagai pengental, penstabil dan pengemulsi, dimana fungsi setil alkohol ini dapat digantikan oleh karagenan. Ekstrak kelopak rosela dengan kandungan vitamin $\mathrm{C}$ dapat melindungi kulit dari radikal bebas. Tujuan dari penelitian ini adalah menentukan konsentrasi terbaik dari penggunaan setil alkohol dan karagenan serta penambahan ekstrak kelopak rosela pada handbody lotion. Metode dari penelitian ini adalah analisis data menggunakan One Way ANOVA dan uji lanjutan duncan serta analisis deskriptif. Tahapan dari penelitian adalah penggunaan setil alkohol (0,5\%; 0,7\%; dan 1\%) dan karagenan (1\%; $2 \%$; dan $3 \%)$ pada pembuatan handbody lotion serta handbody lotion terbaik ditambah dengan ekstrak kelopak rosela 2,5\%. Hasil Penelitian menunjukkan bahwa formula handbody lotion yang dibuat memenuhi SNI 4399-1966 (penampakan, $\mathrm{pH}$, dan viskositas) dimana perlakuan terbaik yaitu setil alkohol 1\% (rendemen 92,8\%; homogen; pH 8,0; viskositas 4950,0 cP) dan karagenan 3\% (rendemen 92,5\%; homogen; $\mathrm{pH}$ 7,0; viskositas $9262,5 \mathrm{cP}$ ). Hasil penelitian menunjukkan bahwa sifat fungsional dari setil alkohol dapat digantikan oleh karagenan. Handbody lotion terbaik dengan penggunaan setil alkohol 1\% ditambah dengan ekstrak kelopak rosela $2,5 \%$ menghasilkan rendemen 92,4\%; penampakan homogen; $\mathrm{pH} 7,0$; viskositas 4266,7 cP. Handbody lotion dengan penggunaan karagenan 3\% ditambah dengan ekstrak kelopak rosela 2,5\% menghasilkan rendemen 92,4\%; penampakan homogen; pH 7,0 ; viskositas $5216,7 \mathrm{cP}$. Penambahan ekstrak kelopak rosela menghasilkan handbody lotion yang memenuhi standar SNI 4399-1996.
\end{abstract}

Kata kunci: ekstrak kelopak rosela; handbody lotion; karagenan; setil alkohol; vitamin c

\begin{abstract}
Handbody lotion is a cosmetic that can be applied to skin of hands and body which functions to reduce skin dehydration. Cetyl alcohol in handbody lotion has a function as a thickener, stabilizer and emulsifier, where the function of cetyl alcohol can be replaced by carrageenan. Roselle petal extract contains vitamin $C$ can protect skin from free radicals. The purpose of this study was to determine the best concentration of cetyl alcohol and carrageenan and addition of roselle petal extract to handbody lotion. The method of this research was data analysis used One Way ANOVA and duncan follow-up test and descriptive. The stages of study were use of cetyl alcohol $(0.5 \% ; 0,7 \%$; and $1 \%)$ and carrageenan (1\%; $2 \%$; and $3 \%)$ in preparation handbody lotion and best handbody lotion added with roselle petal extract $2.5 \%$. The results showed that handbody lotion formula fulfilled SNI 4399-1966 (appearance, $\mathrm{pH}$, and viscosity) where the best treatment was $1 \%$ cetyl alcohol (yield 92.8\%; homogeneous; $\mathrm{pH} 8,0$; viscosity 4950,0 cP) and carrageenan 3\% (yield 92,5\%; homogeneous; $\mathrm{pH}$ 7,0; viscosity 9262,5 cP). The results showed that the function of cetyl alcohol could be replaced by carrageenan. The best handbody lotion with the use of $1 \%$ cetyl alcohol plus 2,5\% roselle petal extract resulted in $92.4 \%$ yield; homogeneous; $\mathrm{pH}$ 7,0; viscosity of $4266,7 \mathrm{cP}$. Handbody lotion with the use of 3\% carrageenan plus $2.5 \%$ roselle petal extract yielded $92.4 \%$ yield; homogeneous; $\mathrm{pH} 7,0$; viscosity $5216.7 \mathrm{cP}$. The addition of roselle petal extract produced handbody lotion fulfilled SNI 4399-1996.
\end{abstract}

Keywords: carrageenan; cetyl alcohol; handbody lotion; roselle petal extract; vitamin c

\section{PENDAHULUAN}

Dehidrasi pada kulit dapat dikurangi dengan menggunakan handbody lotion. Handbody lotion merupakan kosmetika yang dapat mengurangi penguapan air dari kulit dan menarik air dari udara yang masuk ke dalam stratum corneum yang mengalami dehidrasi sehingga dapat melembabkan kulit (Sumbayak \& Diana, 2018). Vitamin C dapat berperan sebagai antioksidan yang diperlukan untuk menjaga fungsi dari kolagen sehingga dapat mengurangi terjadinya kekeriputan pada kulit serta menjaga kekebalan tubuh dari serangan infeksi dan alergi (Winarsi, 2007). Menurut Pangaribuan (2016) vitamin C merupakan antioksidan yang memiliki fungsi melindungi kulit dari serangan radikal bebas dan pengaruh buruk dari sinar ultraviolet (UV).

Salah satu bahan penyusun Handbody lotion adalah setil alkohol yang berfungsi zat pengental, penstabil, dan pengemulsi. Sifat fungsional dari setil alkohol ini dapat digantikan oleh karagenan, adapun kelebihan dari karagenan dibanding setil alkohol yaitu karagenan berfungsi sebagai humektan yang dapat mempertahankan 
kelembaban kulit (Erungan dkk., 2009). Karagenan memiliki sifat sebagai pengembang,pembentuk gel yang baik, dan sebagai penstabil yang baik, sehingga pada farmasetik karagenan ini banyak digunakan sebagai peningkat viskositas (Narang \& Boddu, 2015). Penelitian mengenai pembuatan handbody lotion dengan menggunakan karagenan sebagai pengganti setil alkohol dalam pembuatan handbody lotion telah dilakukan oleh Erungan dkk (2009); Purwaningsih dkk (2014); Tumbelaka dkk (2019); Hardjata dkk (2020). Tipe handbody lotion umumnya terdiri dari 10$15 \%$ fase minyak, $75-85 \%$ fase air, dan $5-10 \%$ humektan (Rahmawanty dkk., 2020). Formulasi handbody lotion dibuat dengan memvariasikan konsentrasi agen pengental, penstabil, dan pengemulsi yaitu setil alkohol dan karagenan. Tipe handbody lotion yang diharapkan adalah tipe minyak dalam air (M/A).Lotion tipe M/A memiliki kelebihan yaitu mudah dicuci dan dibersihkan karena karakteristik fase luar dari tipe ini adalah hidrofilik (Mardikasari dkk., 2017).

Penambahan bahan alami aktif diharapkan dapat meningkatkan nilai tambah dan fungsi dari handbody lotion tanpa memberikan efek iritasi. Penambahan zat alami pada handbody lotion sebagai antioksidan telah dilakukan oleh Purwaningsih $d k k$ (2014) dengan melakukan penambahan ekstrak Rhizopora mucronata; Rahmatullah dkk (2019) dengan penambahan esktrak kulit nanas; Salsabila $d k k$ (2020) dengan melakukan penambahan nanopartikel kitosan dan spirulina $s p$. Zat alami lain yang dapat ditambahkan pada handbody lotion adalah ekstrak kelopak rosela (Hibiscus sabdariffa Linn) mengandung vitamin $\mathrm{C}$ yang dapat dijadikan sebagai zat antioksidan. Tujuan dari penelitian ini adalah menentukan konsentrasi terbaik dari penggunaan setil alkohol dan karagenan serta penambahan ekstrak kelopak rosela pada hanbody lotion.

\section{METODOLOGI}

\section{Metode Penelitian}

Metode Penelitian yang digunakan pada penelitian ini adalah metode eksperimental laboratorium dengan analisis data menggunakan One Way ANOVA dan uji lanjutan duncan serta analisis deskriptif. Penelitian ini terdiri dari 6 perlakuan yaitu perlakuan $A$ (setil alkohol $0,5 \%$ ), perlakuan B (setil alkohol 0,7\%), perlakuan C (setil alkohol 1\%), perlakuan D (karagenan 1\%), perlakuan E (karagenan 2\%), dan perlakuan $\mathrm{F}$ (karagenan 3\%). Perlakuan terbaik akan diberi tambahan konsentrasi ekstrak kelopak rosela 2,5\% (b/b).

\section{Bahan}

Bahan yang digunakan pada penelitian ini adalah ekstrak kelopak rosela yang memiliki nilai kadar vitamin C $37,3764 \mathrm{mg} / 100 \mathrm{~g}$, asam stearat, akuades, gliserin, metil paraben, parafin cair, pewangi jeruk, propil paraben, setil alkohol, trietanolamin, dan indiktor $\mathrm{pH}$ universal.

\section{Alat}

Alat yang digunakan pada penelitian ini adalah beaker glass, mortar dan stemper, waterbath, viskometer, timbangan digital, dan spatula.

\section{Prosedur penelitian}

\section{Pembuatan handbody lotion}

Tabel 1 merupakan formula handbody lotion dengan setil alkohol, tabel 2 merupakan formula handbody lotion dengan karagenan, dan tabel 3 merupakan handbody lotion terbaik dengan penambahan ekstrak kelopak rosela.

Pembuatan dari handbody lotion ini dimulai dengan menimbang bahan-bahan yang akan digunakan. Bahan yang telah ditimbang kemudian dipanaskan pada beaker glass di atas waterbath pada suhu $70-75^{\circ} \mathrm{C}$ hingga melebur, bahan yang dipanaskan ini terdiri dari dua fase yaitu fase minyak (asam stearat, setil alkohol atau karagenan, parafin cair, dan propil paraben) serta fase air (trietanolamin, gliserin, metil paraben, akuades $1 / 3$ bagian). Setelah dipanaskan, fase minyak dimasukan ke dalam mortar sambil diaduk-aduk dengan teknik pengadukan yang cepat dan konstan hingga homogen. Memasukan fase air ke dalam fase minyak sedikit demi sedikit serta tetap dilakukan pengadukan yang cepat hingga homogen. Memasukan ekstrak kelopak rosela ke dalam campuran fase air dan fase minyak yang telah homogen sambil terus diaduk. Menambahkan sisa akuades (2/3 bagian) sedikit demi sedikit sambil terus diaduk secara konstan hingga homogen. Menambahkan pewangi jeruk sedikit demi sedikit sambil terus diaduk hingga homogen. Sediaan yang telah homogen kemudian dimasukkan ke dalam wadah (Modifikasi dari Safitri \& Jubaidah (2019); Slamet \& U (2019)).

Tabel 1. Formula Handbody Lotion dengan Setil Alkohol (300 gram)

\begin{tabular}{lccc}
\hline Bahan & $\mathrm{A}(\mathrm{g})$ & $\mathrm{B}(\mathrm{g})$ & $\mathrm{C}(\mathrm{g})$ \\
\hline Asam Stearat & 7,5 & 7,5 & 7,5 \\
Setil Alkohol & 1,5 & 2,1 & 3 \\
Trietanolamin & 3 & 3 & 3 \\
Gliserin & 15 & 15 & 15 \\
Parafin Cair & 21 & 21 & 21 \\
Metil Paraben & 0,3 & 0,3 & 0,3 \\
Propil Paraben & 0,1 & 0,1 & 0,1 \\
Pewangi & 1,5 & 1,5 & 1,5 \\
Akuades & 250,2 & 249,5 & 248,7 \\
\hline
\end{tabular}

Tabel 2. Formula Handbody Lotion dengan Karagenan (300 gram)

\begin{tabular}{lccc}
\hline Bahan & $\mathrm{D}(\mathrm{g})$ & $\mathrm{E}(\mathrm{g})$ & $\mathrm{F}(\mathrm{g})$ \\
\hline Asam Stearat & 7,5 & 7,5 & 7,5 \\
Karagenan & 3 & 6 & 9 \\
Trietanolamin & 3 & 3 & 3 \\
Gliserin & 15 & 15 & 15 \\
Parafin Cair & 21 & 21 & 21 \\
Metil Paraben & 0,3 & 0,3 & 0,3 \\
Propil Paraben & 0,1 & 0,1 & 0,1 \\
Pewangi & 1,5 & 1,5 & 1,5 \\
Akuades & 248,7 & 245,7 & 242,7 \\
\hline
\end{tabular}

Tabel 3. Formula Handbody Lotion Perlakuan Terbaik dengan Penambahan Ekstrak Kelopak Rosela dalam Satuan Berat (300 gram)

\begin{tabular}{lcc}
\hline \multicolumn{1}{c}{ Nama Bahan } & Perlakuan 1 $(\mathrm{g})$ & Perlakuan 2 $(\mathrm{g})$ \\
\hline Ekstrak Kelopak & 7,5 & 7,5 \\
Rosela & 7,5 & 7,5 \\
Asam Stearat & 3 & - \\
Setil Alkohol & - & 9 \\
Karagenan & 3 & 3 \\
Trietanolamin & 15 & 15 \\
Gliserin & 21 & 21 \\
Parafin Cair & 0,3 & 0,3 \\
Metil Paraben & 0,1 & 0,1 \\
Propil Paraben & 1,5 & 1,5 \\
Pewangi & 241,2 & 235,2 \\
Akuades & & \\
\hline
\end{tabular}

2. Perhitungan rendemen 
Perhitungan rendemen dilakukan dengan cara menimbang massa awal bahan-bahan penyusun handbody lotion dan massa akhir (handbody lotion yang dihasilkan). kemudian perhitungan rendemen dilakukan dengan menggunakan rumus sebagai berikut:

Rendemen $=\frac{\text { Massa akhir }}{\text { Massa awal }} \times 100 \%$.

\section{Uji pH}

Uji pH pada handbody lotion dilakukan dengan cara menggoreskan $\mathrm{pH}$ stick ( $\mathrm{pH}$ universal) pada sampel, kemudian $\mathrm{pH}$ handbody lotion dapat dilihat dari perubahan warna yang terjadi pada $\mathrm{pH}$ stick (Slamet \& U, 2019).

\section{Uji viskositas}

Uji viskositas dilakukan dengan menggunakan viskometer brokfield spindel nomor 4 dan kecepatan $60 \mathrm{rpm}$. Langkah pertama yang dilakukan adalah menyiapkan alat yang akan digunakan kemudian meletakan sampel \pm 100 gram di bawah batas tanda yang ada pada spindel. Menghidupkan alat dan mencatat hasil yang didapatkan (Modifikasi dari Megantara dkk (2017). Hasil dari viskositas dapat dihitung dengan menggunakan rumus sebagai berikut:

Viskositas $=$ Dial Reading $\times$ Faktor.

\section{Uji homogenitas}

Uji homogenitas dilakukan dengan cara meletakan sampel pada cawan petri kemudian dilihat homogenitasnya (Tumbelaka dkk., 2019).

\section{HASIL DAN PEMBAHASAN}

\section{Pembuatan handbody lotion}

Handbody lotion yang dibuat terdiri dari dua fase yaitu fase minyak dan fase air. Handbody lotion yang dibuat merupakan tipe lotion minyak dalam air (M/A). Lotion tipe M/A dapat disebabkan oleh pelarut yang digunakan dalam pembuatan handbody lotion ini yaitu berupa akuades (Megantara $d k k ., 2017$ ).

Pembuatan handbody lotion ini menggunakan prinsip berupa pencampuran beberapa bahan yang disertai dengan pemanasan dan pengadukan yang konstan dan secara terus menerus. Fase minyak dan fase air dipanaskan di atas waterbath pada suhu $75^{\circ} \mathrm{C}$. Pemanasan ini bertujuan untuk melarutkan kedua fase. Fase minyak masuk ke dalam mortar sambil terus diaduk dengan pengadukan yang konstan sampai homogen, kemudian ditambahkan fase air sedikitdemi sedikit sambil terus diaduk. Sisa akuades $2 / 3$ bagian ditambahkan juga secara sedikit demi sedikit sambil terus diaduk hingga konstan kemudian tahap terakhir dari pembuatan handbody lotion ini adalah menambahkan pewangi (minyak jeruk) ke dalam handbody lotion. Pengadukan yang dilakukan harus dilakukan secara terus menerus dan konstan agar handbody lotion yang dihasilkan tidak beragregat.

Penggunaan setil alkohol pada pembuatan handbody lotion berfungsi sebagai emulsifying agent dan thicking agent. Kombinasi dari penggunaan setil alkohol dan asam stearat pada pembuatan handbody lotion memiliki fungsi sebagai agen pengental yang dapat menjaga stabilitas dari handbody lotion serta dapat membentuk lapisan yang mengelilingi fase minyak sehingga dapat mengakibatkan fase minyak terdispersi pada fase air. Penggunaan Trietanolamin (TEA) berfungsi untuk menurunkan $\mathrm{pH}$ atau keasaman dari asam stearat yang dapat menyebabkan terjadinya iritasi pada kulit (Tumbelaka dkk., 2019).
Penggunaan karagenan dalam pembuatan handbody lotion ini yaitu untuk mengganti fungsi dari setil alkohol. Menurut Rowe dkk (2009) karagenan merupakan jenis hidrokoloid yang dapat mengentalkan larutan.

\section{Rendemen handbody lotion}

Tabel 4 dan Tabel 5 menunjukan rendemen dari 6 (enam) perlakuan handbody lotion.

Tabel 4. Rendemen Handbody Lotion dengan Setil Alkohol

\begin{tabular}{cccc}
\hline Perlakuan & $\begin{array}{c}\text { Massa } \\
\text { Awal } \\
\text { (gram) }\end{array}$ & $\begin{array}{c}\text { Massa } \\
\text { Akhir } \\
\text { (gram) }\end{array}$ & Rendemen (\%) \\
\hline $\mathrm{A}$ & 300 & 277,2 & $92,4 \pm 0,3^{\mathrm{a}}$ \\
$\mathrm{B}$ & 300 & 278,5 & $91,4 \pm 0,8^{\mathrm{a}}$ \\
$\mathrm{C}$ & 300 & 274,1 & $92,8 \pm 0,7^{\mathrm{a}}$ \\
\hline Keterangan: & Superscripts dengan & huruf yang & berbeda menunjukkan
\end{tabular}
perlakuan yang berbeda nyata

Tabel 5. Rendemen Handbody Lotion dengan Karagenan

\begin{tabular}{cccc}
\hline Perlakuan & $\begin{array}{c}\text { Massa } \\
\text { Awal } \\
(\text { gram })\end{array}$ & $\begin{array}{c}\text { Massa } \\
\text { Akhir } \\
(\text { gram })\end{array}$ & Rendemen (\%) \\
\hline D & 300 & 273,2 & $91,4 \pm 1,3^{\mathrm{a}}$ \\
E & 300 & 276,9 & $92,2 \pm 1,4^{\mathrm{a}}$ \\
$\mathrm{F}$ & 300 & 277,4 & $92,5 \pm 1,4^{\mathrm{a}}$ \\
\hline Keterangan: & Superscripts dengan & huruf yang & berbeda menunjukkan
\end{tabular}
perlakuan yang berbeda nyata

Hasil uji statisik menunjukkan variasi konsentrasi setil alkohol tidak berpengaruh nyata terhadap rendemen handbody lotion yang dihasilkan dengan nilai signifikansi 0,239 dan variasi konsentrasi karagenan tidak berpengaruh nyata terhadap rendemen handbody lotion yang dihasilkan dengan nilai signifikansi 0,733 . Berdasarkan perhitungan rendemen yang telah dilakukan menunjukan bahwa terjadi penurunan bobot massa pada handbody lotion, sehingga rendemen yang dihasilkan tidak $100 \%$. Penurunan bobot massa pada pembuatan handbody lotion ini dapat diakibatkan karena adanya proses penguapan pada saat pemanasan bahan, selain itu pemanasan bahan menggunakan beaker glass kemudian dipindahkan pada mortar dapat mengakibatkan adanya bahan yang tertinggal pada beaker glass. Selain itu, pemindahan handbody lotion yang telah selesai dibuat dari mortar ke wadah handbody lotion juga dapat menjadi penyebab terjadinya penyusutan bobot massa pada handbody lotion.

\section{Uji pH handbody lotion}

Tabel 6 dan Tabel 7 menunjukan hasil dari pengujian $\mathrm{pH}$ handbody lotion untuk semua perlakuan.

Tabel 6. pH Handbody Lotion dengan Setil Alkohol

\begin{tabular}{cc}
\hline Perlakuan & $\mathrm{pH}$ \\
\hline $\mathrm{A}$ & $8,0 \pm 0,5^{\mathrm{a}}$ \\
$\mathrm{B}$ & $8,0 \pm 0,5^{\mathrm{a}}$ \\
$\mathrm{C}$ & $8,0 \pm 0,5^{\mathrm{a}}$ \\
\hline Keterangan:Superscripts dengan huruf yang berbeda menunjukkan perlakuan
\end{tabular}
yang berbeda nyata

Tabel 7. pH Handbody Lotion dengan Karagenan

\begin{tabular}{cc}
\hline Perlakuan & $\mathrm{pH}$ \\
\hline $\mathrm{D}$ & $8,0 \pm 0,5^{\mathrm{a}}$ \\
$\mathrm{E}$ & $8,0 \pm 0,5^{\mathrm{a}}$ \\
$\mathrm{F}$ & $7,0 \pm 0,5^{\mathrm{a}}$ \\
\hline
\end{tabular}

Keterangan:Superscripts dengan huruf yang berbeda menunjukkan perlakuan yang berbeda nyata 
Hasil uji statisik menunjukkan variasi konsentrasi setil alkohol tidak berpengaruh nyata terhadap $\mathrm{pH}$ handbody lotion yang dihasilkan dengan nilai signifikansi 1,000 dan variasi konsentrasi karagenan tidak berpengaruh nyata terhadap rendemen handbody lotion yang dihasilkan dengan nilai signifikansi 0,385 . Berdasarkan hasil pengujian $\mathrm{pH}$ menunjukan bahwa untuk handbody lotion dengan menggunakan setil alkohol sebagai pengental, pengemulsi, dan penstabil memiliki pH 8,0 baik untuk konsentrasi $0,5 \%$ maupun $1 \%$. Sedangkan, penggunaan karagenan pada pembuatan handbody lotion yang berfungsi sebagai pengganti setil alkohol mengalami penurunan $\mathrm{pH}$ pada konsentrasi $3 \%$ yaitu memiliki $\mathrm{pH} 7,0$. Penurunan $\mathrm{pH}$ pada handbody lotion dengan konsentrasi karagenan yang lebih besar ini tidak sejalan dengan penelitian yang dilakukan oleh Erungan dkk (2009) dimana nilai $\mathrm{pH}$ dari handbody lotion dengan karagenan lebih besar daripada nilai $\mathrm{pH}$ handbody lotion dengan setil alkohol. Namun meski begitu nilai pH yang dihasilkan untuk semua perlakuan masih berada pada nilai pH yang ditentukan oleh SNI 4399-1996 untuk sediaan tabir surya yaitu berkisar 4,5-8,0. Menurut Safitri \& Jubaidah (2019) nilai $\mathrm{pH}$ yang terlalu rendah dari 4,5 dapat mengakibatkan iritasi dan gatal pada kulit, sedangkan nilai $\mathrm{pH}$ yang lebih tinggi dari 8,0 dapat mengakibatkan kulit menjadi licin, kering, dan mempengaruhi elastisivitas dari kulit.

\section{Uji viskositas handbody lotion}

Tabel 8 dan Tabel 9 menunjukan hasil dari pengujian viskositas handbody lotion untuk semua perlakuan.

Tabel 8. Viskositas Handbody Lotion dengan Setil Alkohol

\begin{tabular}{cc}
\hline Perlakuan & Viskositas (cP) \\
\hline A & $3750,0 \pm 0,0^{\mathrm{a}}$ \\
B & $4200,0 \pm 70,7^{\mathrm{b}}$ \\
C & $4950,0 \pm 70,7^{\mathrm{c}}$ \\
\hline
\end{tabular}

Keterangan:Superscripts dengan huruf yang berbeda menunjukkan perlakuan yang berbeda nyata

Tabel 9. Viskositas Handbody Lotion dengan Karagenan

\begin{tabular}{cc}
\hline Perlakuan & Viskositas (cP) \\
\hline D & $3925,0 \pm 35,4^{\mathrm{a}}$ \\
E & $4975,0 \pm 35,4^{\mathrm{b}}$ \\
F & $9262,5 \pm 88,4^{\mathrm{c}}$ \\
\hline Keterangan:Superscripts
\end{tabular}

Keterangan:Superscripts dengan huruf yang berbeda menunjukkan perlakuan yang berbeda nyata

Hasil uji statisik menunjukkan variasi konsentrasi setil alkohol berpengaruh nyata terhadap viskositas handbody lotion yang dihasilkan dengan nilai signifikansi 0,001 dan variasi konsentrasi karagenan berpengaruh nyata terhadap viskositas handbody lotion yang dihasilkan dengan nilai signifikansi 0,000 . Berdasarkan hasil pengujian viskositas yang dilakukan pada handbody lotion dapat dilihat bahwa nilai viskositas handbody lotion untuk semua perlakuan masih ada pada rentang nilai viskositas handbody lotion berdasarkan SNI 4399-1996 untuk sediaan tabir surya yaitu 2.000 - $50.000 \mathrm{cP}$. Nilai viskositas dengan konsentrasi karagenan yang paling tinggi $(3 \%(b / b))$ menghasilkan nilai viskositas yang paling tinggi yaitu sebesar 9262,5 cP. Semakin tinggi konsentrasi karagenan yang digunakan akan semakin tinggi nilai viskositas handbody lotion yang dihasilkan, dimana konsentrasi karagenan lebih dari $3 \%$ dapat menyebabkan handbody lotion menjadi sulit untuk dituang dan cenderung berbentuk pasta sampai padat (krim) (Erungan dkk., 2009). Perbedaan nilai viskositas juga dapat disebabkan karena adanya perbedaan gaya yang diberikan ketika proses pencampuran atau proses pengadukan fase minyak dan fase air. Menurut Ansel (1989) viskositas dari suatu sediaan dipengaruhi oleh beberapa faktor yang salah satunya yaitu faktor pencampuran atau faktor pengadukan saat proses pembuatan sediaan.

\section{Uji homogenitas handbody lotion}

Tabel 10 menunjukan hasil dari pengujian homogenitas handbody lotion untuk semua perlakuan.

\begin{tabular}{cc} 
Tabel 10. Hasil Uji Homogenitas Handbody Lotion \\
\hline Perlakuan & Homogenitas \\
\hline A & Homogen \\
B & Homogen \\
C & Homogen \\
D & Homogen \\
E & Homogen \\
F & Homogen \\
\hline
\end{tabular}

Berdasarkan hasil penelitian menunjukan bahwa semua perlakuan menunjukan penampakan yang homogen. Handbody lotion yang homogen apabila dioleskan pada cawan petri tidak terasa adanya bahan padat pada cawan petri. Sediaan dikatakan homogen apabila tidak adanya agregasi partikel sekunder, penghalusan partikel primer yang besar, serta distribusi yang merata dari fase terdispersi (Voigt, 1995). Berdasarkan Tabel 10, dapat dilihat bahwa seluruh perlakuan homogen dan telah memenuhi standar SNI 4399-1996 untuk sediaan tabir surya. Hal ini menunjukan bahwa sediaan telah tercampur dengan baik, hal ini menunjukan bahwa penggunaan setil alkohol maupun karagenan sebagai agen pengental, penstabil dan pengemulsi tidak mempengaruhi homogenitas dari sediaan handbody lotion yang dihasilkan.

\section{Pemilihan handbody lotion terbaik}

Pemilihan handbody lotion terbaik dilihat berdasarkan parameter $\mathrm{pH}$, viskositas, dan homogenitas. Handbody lotion yang diharapkan adalah handbody lotion yang memiliki $\mathrm{pH}$ pada rentang SNI 4399-1996 yaitu 4,5-8,0, memiliki penampakan yang homogen berdasarkan SNI 4399-1996 dan memiliki nilai viskositas yang ada pada rentang SNI 4399-1996 yaitu 2.000-50.000 cP. Pada penelitian ini konsentrasi setil alkohol dan karagenan yang dipilih adalah yang memiliki nilai viskositas yang paling tinggi. Handbody lotion yang memiliki nilai viskositas yang tinggi akan lebih stabil dibanding dengan handbody lotion yang memiliki nilai viskositas yang rendah (Wulanawati dkk., 2019). Tabel 11 menunjukan hasil rekapitulasi handbody lotion.

Tabel 11. Rekapitulasi handbody lotion

\begin{tabular}{lccccccc}
\hline \multicolumn{1}{c}{ Parameter } & $\mathrm{A}$ & $\mathrm{B}$ & $\mathrm{C}$ & $\mathrm{D}$ & $\mathrm{E}$ & $\mathrm{F}$ & Standar \\
\hline $\mathrm{pH}$ & 8,0 & 8,0 & 8,0 & 8,0 & 8,0 & 7,0 & $4,5-8,0$ \\
Viskositas (cP) & 3750,0 & 4200,0 & 4950,0 & 3925,0 & 4975,0 & 9262,5 & $\begin{array}{c}\text { Nilai } \\
\text { viskositas } \\
\end{array}$ \\
& & & & & & tertingi \\
Homogenitas & Homogen & Homogen & Homogen & Homogen & Homogen & Homogen & Homogen \\
\hline
\end{tabular}


Berdasarkan hasil rekapitulasi menunjukan bahwa untuk handbody lotion dengan setil alkohol perlakuan terbaik adalah perlakuan $\mathrm{C}$ dimana memilik $\mathrm{pH}$ 8,0; viskositas 4950,0 cP; dan homogen. Sedangkan perlakuan terbaik untuk handbody lotion dengan karagenan perlakuan terbaik adalah perlakuan $\mathrm{F}$ dimana memiliki $\mathrm{pH} 7,0$; viskositas 9262,5cP; dan homogen. Perlakuan terbaik pada 2 (dua) perlakuan ini kemudian ditambahkan ekstrak kelopak rosela dengan konsentrasi yang berbeda. Tabel 12 menunjukan hasil dari pengujian handbody lotion dengan penambahan ekstrak kelopak rosela.

Tabel 12.Hasil Uji Handbody Lotion dengan Penambahan Ekstrak Kelopak Rosela

\begin{tabular}{lcc}
\hline \multicolumn{1}{c}{ Parameter } & Perlakuan 1 & Perlakuan 2 \\
\hline Rendemen (\%) & 92,4 & 92,4 \\
$\mathrm{pH}$ & 7,0 & 7,0 \\
Viskositas (cP) & 4266,7 & 5216,7 \\
Homogenitas & Homogen & Homogen \\
\hline
\end{tabular}

Keterangan: Perlakuan 1: Handbody lotion dengan konsentrasi setil alkohol 1\%. Perlakuan 2: Handbody lotion dengan konsentrasi karagenan 3\%

Nilai rendemen untuk perlakuan 1 dan perlakuan 2 sama serta semua perlakuan mengalami penurunan bobot massa. Nilai viskositas handbody lotion dengan menggunakan konsentrasi karagenan $3 \%$ lebih tinggi apabila dibandingkan dengan nilai viskositas handbody lotion dengan konsentrasi setil alkohol 1\%. Nilai viskositas karagenan lebih besar dari setil alkohol karena pada pembuatan handbody lotion karagenan hanya bertindak sebagai agen pengental pada handbody lotion yang menyebabkan viskositas bertambah, sedangkan penggunaan setil alkohol hanya berperan sebagai surfaktan pada sintesis handbody lotion (Tumbelaka dkk., 2019). Nilai pH pada handbody lotion dengan penambahan ekstrak kelopak rosela baik untuk handbody lotion dengan setil alkohol maupun dengan karagenan memiliki $\mathrm{pH}$ yang sama yaitu 7,0 .

Penambahan ekstrak kelopak rosela menyebabkan nilai $\mathrm{pH}$ dan viskositas mengalami penurunan dibandingkan dengan handbody lotion tanpa penambahan ekstrak kelopak rosela, turunnya $\mathrm{pH}$ dapat disebabkan karena ekstrak yang digunakan bersifat asam. Sedangkan, turunnya viskositas disebabkan karena ekstrak yang digunakan adalah ekstrak cair (kurang kental). Hasil pengujian menunjukan bahwa perlakuan 1 dan perlakuan 2 memenuhi standar SNI 43991996 untuk parameter $\mathrm{pH}$, viskositas (cP), dan homogenitas. Hal ini berarti bahwa ekstrak kelopak rosela dapat diaplikasikan sebagai zat alami pada pembuatan handbody lotion.

\section{KESIMPULAN}

Formula handbody lotion yang dibuat untuk semua perlakuan memenuhi SNI 4399-1966 (penampakan, $\mathrm{pH}$, dan viskositas) dimana perlakuan terbaik yaitu setil alkohol $1 \%$ (rendemen 92,8\%; homogen; $\mathrm{pH} 8,0$; viskositas 4950,0 cP) dan karagenan $3 \%$ (rendemen $92,5 \%$; homogen; $\mathrm{pH} 7,0$; viskositas $9262,5 \mathrm{cP}$, hal ini menunjukan bahwa sifat fungsional dari setil alkohol dapat digantikan oleh karagenan, sehingga kedua jenis agen pengental, penstabil, dan pengemulsi ini dapat digunakan dalam formulasi handbody lotion. Handbody lotion terbaik dengan penggunaan setil alkohol $1 \%$ ditambah dengan ekstrak kelopak rosela $2,5 \%$ menghasilkan rendemen 92,4\%; penampakan homogen; $\mathrm{pH}$ 7,0; viskositas 4266,7 cP. Handbody lotion dengan penggunaan karagenan $3 \%$ ditambah dengan ekstrak kelopak rosela $2,5 \%$ menghasilkan rendemen 92,4\%; penampakan homogen; $\mathrm{pH} 7,0$; viskositas $5216,7 \mathrm{cP}$. Penambahan ekstrak kelopak rosela menghasilkan handbody lotion yang memenuhi standar SNI 4399-1996, sehingga ekstrak kelopak rosela dapat diaplikasikan pada pembuatan handbody lotion.

\section{DAFTAR PUSTAKA}

Ansel, H. C. 1989. Pengantar Bentuk Sediaan Farmasi. Cetakan I. Diedit oleh Ibrahim, F. Jakarta: UI Press.

Erungan, A. C., Purwaningsih, S. \& Anita, S. B. 2009. "Aplikasi Karaginan dalam Pembuatan Skin Lotion," XII(2), hal. 128-143.

Hardjata, D. A., Romadhon \& Rianingsih, L. 2020. "Karakteristik Fisiko-Kimia Skin Lotion Ekstrak Albumin Ikan Gabus (Channa striata)," Jurnal IImu dan Teknologi Perikanan, 2(2), hal. 31-41.

Mardikasari, S. A., Mallarangeng, A. N. T. A., Zubaydah, W. O. S. \& Juswita, E. 2017. "Formulasi dan Uji Stabilitas Lotion dari Ekstrak Etanol Daun Jambu Biji (Psidium guajava L.) Sebagai Antioksidan," Jurnal Farmasi, $3(2)$, hal. 28-32.

Megantara, I., Megayanti, K., Wirayanti, R., Esa, I., Wijayanti, N. \& Yustiantara, P. 2017. "Formulasi Lotion Ekstrak Buah Raspberry (Rubus rosifolius) dengan Variasi Konsentrasi Trietanolamin Sebagai Emulgator serta Uji Hedonik terhadap Lotion," Farmasi Udayana, 6(1), hal. 1-5.

Narang, A. S. \& Boddu, S. H. 2015. Exipient Application in Formulation Design and Drug Delivery. Switzerland: Springer.

Pangaribuan, L. 2016. "Pemanfaatan Masker Bunga Rosela untuk Pencerahan Kulit Wajah," Jurnal Keluarga Sehat Sejahtera, 14(28), hal. 46-58.

Purwaningsih, S., Salamah, E. \& Budiarti, T. . 2014. "Formulasi Skin Lotion dengan Penambahan Karagenan dan Antioksidan Alami dari Rhizophora mucronata Lamk .," V(1), hal. 55-62.

Rahmatullah, S., Permadi, Y. W. \& Utami, D. S. 2019. "Formulasi dan Uji Aktivitas Antioksidan Sediaan Hand and Body Lotion Ekstrak Kulit Nanas (Ananas comosus (L.) Merr) dengan Metode DPPH," JF FIK UNKAM, 7(1), hal. 26-33.

Rahmawanty, D., Annisa, N. \& Sari, D. I. 2020. "Formulasi Sediaan Kosmetik (Lotion Antioksidan) dari Tanaman Bangkal ( Nauclea Subdita ( KORTH .) STEUD .)," Prosiding Seminar Nasional Lingkungan Lahan Basah, 5(2), hal. 25-29.

Rowe, R., Sheskey, P. \& Quinn, M. 2009. Handbook of Pharmaceutical excipient, Sixth Edition. Washington: American Pharmaceutical Association.

Safitri, C. I. N. H. \& Jubaidah, L. 2019. "Formulasi dan Uji Mutu Fisik Sediaan Lotion Ekstrak Kulit Buah Jagung (Zea mays L.)," Jurnal Insan Farmasi Indonesia, 2(2), hal. 175-184. doi: 10.36387/jifi.v2i2.394.

Salsabila, Nazmah, Indratmoko, Septiana \& Andi, Tenri 2020. "Pengembangan Hand \& Body Lotion Nanopartikel Kitosan dan Spirulina Sp sebagai Antioksidan," Jurnal IImiah JOPHUS: Journal Of Pharmacy UMUS, 2(01), hal. 11-20. doi: 10.46772/jophus.v2i01.268.

Slamet, S. \& U, Waznah. 2019. "Optimasi Formulasi Sediaan Handbody Lotion Ekstrak Daun Teh Hijau (Camellia sinensis Linn)," Jurnal Pena, 33(1), hal. 53-57.

Sumbayak, A. R. \& Diana, V. E. 2018. "Formulasi Hand Body Lotion Ekstrak Etanol Kulit Buah Semangka (Citrillus vulgaris)," Jurnal Dunia Farmasi, 2(2), hal. 70-76.

Tumbelaka, Riddel M. M. Y., Momuat, Lidya I. \& Wuntu, Audy D. 2019. "Pemanfaatan VCO Mengandung Karotenoid Tomat dan Karagenan dalam Pembuatan Lotion," Pharmacon, 8(1), hal. 94-105. 
Voigt, R. 1995. Buku Pelajaran Teknologi Farmasi. Diedit oleh Soewandhi, S. S., B. Mathilda, dan Widianto. Yogyakarta: Gadjah Mada University Press.

Winarsi, H. 2007. Antioksidan Alami \& Radikal Bebas. Yogyakarta: Kanisius.

Wulanawati, A., Epriyani, C. \& Sutanto, E. 2019. "Analisis Stabilitas Lotion Menggunakan Emulsifier Hasil Penyabunan Minyak dan Alkali," Jurnal Farmamedika, 1(4), hal. 23-28. 